\title{
The Application of Scientific Plus Learning to Improve Mathematics Learning Achievement of Junior High School Students Grade VII
}

\author{
La Ode Ahmad Jazulia, Mustamin Anggo ${ }^{a}$, Utu Rahima ${ }^{a}$, Latief Sahidin ${ }^{a}$, \\ Salima
}

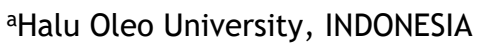

\begin{abstract} Learning will be meaningful if it links the students' real-life experiences with mathematical ideas or concepts in learning process through contextual issues. One of the meaningful mathematics and mathematical oriented learning in daily life experiences is scientific plus learning. The purpose of this research was to describe the students' spiritual attitude and social competence, learning skills, and the improvement of students' Mathematics achievement on the material "Numbers" in class VII.B of Junior High School of Satria Kendari through a scientific plus approach. This research was classroom action research and the subject of this research consisted of 34 students of class VII.B of Junior High School of Satria Kendari. The results showed that the students' spiritual attitude were in the good category, social attitudes were in the good category, learning skills was predicated B+, Mathematics achievement was completed in the cycle IV with the average score was 79.96 and the percentage of completeness was $81.81 \%$ predicated $A$, and the learning management that was applied through a scientific plus approach by the teacher achieved $86 \%$ in the fourth cycle.
\end{abstract}

KEYWORDS

Scientific plus, Mathematics, learning outcomes
ARTICLE HISTORY

Received 10 August 2017 Revised 28 September 2017 Accepted 15 November 2017

\section{Introduction}

Mathematics learning in Junior High School level needs to be designed properly through activities by using a variety of models, approaches or methods that already exist. The result can be seen from the output emphasized on the

\section{CORRESPONDENCE LD.A. Jazuli $\$ salimpsa@gmail.com}

\section{(c) 2017 LD.A. Jazuli et al.}

Open Access terms of the Creative Commons Attribution 4.0 International License apply. The license permits unrestricted use, distribution, and reproduction in any medium, on the condition that users give exact credit to the original author(s) and the source, provide a link to the Creative Commons license, and indicate if they made any changes. (http://creativecommons.org/licenses/by/4.0/) 
quality through the students' achievement. According to Reigeluitn in Ahiri (2008), the measurement of learning achievement can be seen in the level of one's learning abilities demonstrated by their behavior changes as a result of experience. The achievement is observable behaviors and it demonstrates the ability of a person. Sardiman (2007) argues that the learning outcomes which are achieved always bring knowledge and understanding or cause a reaction or an answer that can be understood and accepted by the mind.

The difficulty to understand and master the mathematics is still a serious problem especially for Junior High School students. Besides, there are still the majority of students who admit mathematics as a frightening specter. This is where the role of teachers is very important in education because the teachers directly deal with the students. Teachers should be able to plan an interesting, effective, and meaningful mathematics lesson. When planning lessons, it is important to encourage students to participate in learning. In reality, there are many students who are still afraid to express themselves. Most of students are passive and the others are dominant. The learning management applied by the teacher is still teacher-centered where teacher is dominant as a determinant of the course of the learning process as well as the only source lesson for students. Besides, there are still passive students who just sit and keep silent in receiving lessons delivered by the teacher and there are students who do not involve themselves physically and mentally in the learning process in the classroom.

Mathematics learning conditions in Junior high school above describes that learning process issues that still need to be optimized are the involvement of students' mental and physical activities in order to align with the learning achievement given by the teacher. Accordingly, it requires a study of collaborative among fellow educators to improve the learning process of teachers through Action Research (PTK) associated with the spirit of scientific curriculum in 2013 and considering an approach to meaningful learning which allows students to interact each other can stimulate skills and creativity of students.

Meaningful learning is needed especially for materials which are interconnected as well as the matter of Numbers that are not merely memorized, but rather the understanding of meaningful concepts. In this case, learning will be meaningful if it relates the students' real-life experiences to mathematical ideas or concepts in learning process in the classroom through contextual problems. One of the mathematics meaningful learning and mathematical oriented daily life experience learning is Scientific Plus Learning.

Scientific plus learning is a combination of scientific learning and realistic mathematics learning. Varelas and Ford (2009) point out the scientific method has the characteristics of "doing science". This method allows teachers or curriculum developers to improve the learning process, namely by breaking the process down into steps or stages in detail which contains instructions for the students carry out learning activities. Budiyanto et al (2016) pinpoint that the approach is scientifically believed to be the golden bridge and the development of attitudes, skills and knowledge of students. The result of scientific approach based learning is more effective than traditional learning.

Scientific mathematics is a European project that involves interdisiplinary cooperation between mathematics and science. It aims to develop a comprehensive and multidimensional learning toward the content and concepts of mathematics. In mathematics, scientific approach steps consist of collecting 
data from the experiment of development and investigation of a mathematical model in the different representation form, and reflection (Beckmann et al, 2009). The specific mathematical scientific approach in curriculum 2013 applied in Indonesia describes the five steps of learning namely: observing facts (mathematics), asking, reasoning, trying, and concluding (Kemendikbud, 2013).

Learning objectives of scientific approach is based on the superiority of the approach such as (1) to increase the intellectual ability especially high-level thinking skills, (2) to establish a capacity student in solving a problem systematically, (3) the creation of the learning conditions where students feel that learning is a requirement, (4) obtaining a high learning outcomes, (5) to train students in expressing their ideas, especially in writing scientific articles, and (6) to develop the students' characters (Machin, 2014).

Realistic Mathematics Learning is one of the mathematics learning approaches on a philosophical basis that is in line with constructivist philosophy. Realistic mathematics approach is a learning approach which is based on the real things for students emphasizing on the skills 'process of doing mathematics', discussing and collaborating, arguing with classmates so that students can find themselves ( 'student inventing as opposed 'teacher telling') and ultimately use the mathematics to solve the problem both individually and in groups. In this approach, the teacher's role is nothing more than a facilitator, moderator or evaluator while students think, communicate their 'reasoning', practice the nuances of democracy by respecting the opinions of others. According to Idris and Silalahi (2016), realistic mathematics approach centered on students can form their own knowledge through their activeness in the classroom. This approach is a learning approach that is more concerned with the activity of students in learning process in the classroom so that students are able to build their own knowledge of the problems that exist in mathematics.

Jan De Lange in (Jazuli, 2007) describes (model schematic) of realistic mathematics learning which is the process of the development of ideas and concepts that start from the real world (contextual issues) as in the following picture:

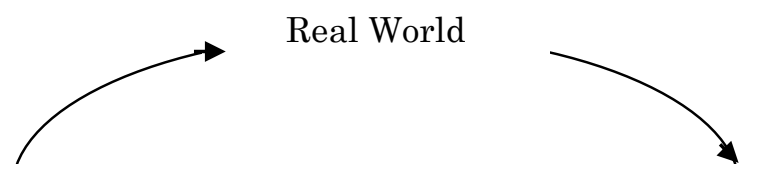

Mathematization in Application

Mathematization and Reflection
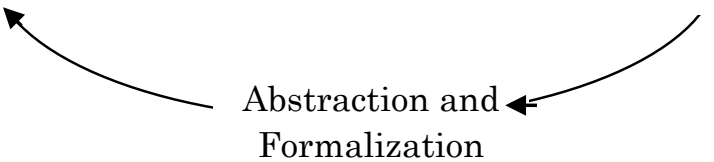

Figure 1: Conceptual Mathematization

The steps of core activities in realistic mathematics learning by Jazuli (2010) as follow:

a. Read and understand the contextual issues

The teacher provides contextual issues and asks the students to understand the problem. If there are certain parts that are lacking or not 
understood by some students, then the students who understand the part are asked to explain it to their friends who have not understood. If the students who have not understood are dissatisfied, the teacher explains further by providing limited instructions or suggestions (as necessary) about the situation and condition of the problem.

b. Resolve the contextual problems.

Students are individually asked to solve contextual problems in their own way. The different solutions and answer of problems are preferred. Teacher motivates students to solve the problem by providing questions that encourage students get the problem solving. In this stage, students are guided to rediscover the concept or principle of mathematics through a given contextual problem. Moreover, students are also directed to form and use their own models to make it easier to solve the problem.

c. Compare and discuss the answers

Students are asked to compare and discuss their answers in small groups. After that, the results of the discussion are compared in the classroom discussion led by the teacher. This stage can be used to train students' courage to express their opinions, even though if their opinions are different from the other friends or their teacher.

d. Conclude

Based on the results of group and class discussion conducted, the teacher directs students to draw conclusions about concepts or definitions, theorems, principles or mathematical procedures associated with newly completed contextual issues.

\section{Method}

This research is Class Action Research. The typical characteristic of action research is that the actions to improve certain teaching and learning process in the classroom. The subject of this research was students grade VII.B of Junior High School of Satria in Kendari which consisted of 34 students. They were divided into 6 groups in which three groups consisted of 5 students and the other groups consisted of 6 students.

This class action research had been conducted in 4 cycles. Each cycle reflected the changes achieved. The procedure of this research as follows:

1. Planning

a. The researchers designed the Lesson Plans (LP) that consisted of 4 LPs adjusting to the number of meetings in each cycle. There were two meetings in one week in which the first meeting was 2 hours and the second meeting was 3 hours so that the number of lessons / week was 5 hours.

b. The researchers organized and determined the issues contained in the students' books highlighted the discussion in every meeting of the material Numbers.

c. The researchers made an observation sheet to see the teaching and learning activities in the classroom when the scientific learning approach plus was applied.

d. The researchers designed the evaluation tool for 4 times of test and the evaluation tool was given at the end of the goal cycle to see the improvement of students' ability, where the evaluation tool made was adjusted to the number of cycles in the subject matter Numbers. 
2. The researchers made an action that carried out the lesson plans by implementing scientific plus learning approach that had been designed.

3. The researchers did observation; it was to carry out the process of observation of the implementation of the action by using the observation sheet that had been made.

4. The researchers and teacher did reflection; it was to analyze the results of observation andevaluation. In this step, the weaknesses in the previous cycle were covered in the next cycle

The indicators to measure the success ofthis research as follow: (1) the assessment of students' spiritual attitude wasindicated in good category, (2) the assessment of the students' social attitudes was indicated in good category, (3) the assessment of students' skill with criterion $\geq 2.66$ or predicate B-,(4) students' mathematics achievement were completed if $\geq 80 \%$ of students were categorized completed.Complete category of students' learning achievement was gained when the students gained value $\geq 75$ (on a scale of 100 ) or $\geq 2.66$ (ona scale of 4 ) or the predicate $\mathrm{B}+,(5)$ teacher's competence to manage learning process $\geq$ $85 \%$ based on the lesson plans.

\section{Result and Discussion}

In the implementation, this class action research consisted of 4 cycles; each cycle consisted of 1 meeting. The learning process is carried out by using approach of scientific plus learning. The scientific study approach becomes an absolute requirement to be applied in the curriculum of 2013 so that students can gain a scientific experience that is trained in the learning process. In addition, the scientific approach to learning becomes a trending topic that many people discuss in education field today. The scientific approach in its presence is as an absolute requirement that teachers must be able to apply questions and challenges to be implemented effectively, so that teachers' innovative strategies are needed in order to guide students through observing, questioning, trying, reasoning and concluding experiences.

One of the strategy innovations pursued in the effort to improve the learning of mathematics in class VII.B of Junior High School of Satria Kendari is to combine the scientific approach with the Realistic Mathematical Learning (PMR) approach. The integration of these two approaches is intended to strengthen the scientific approach with PMR approach so that the students' scientific learning experience (observing, asking, trying, reasoning and concluding) is guided by the activities / steps of the Realistic Mathematics Learning Approach (PMR). The results of such integration are further mentioned in this research by the scientific plus approach.

Scientific Plus approach is considered particularly suitable to improve learning conditions in class VII. B of Junior High School of Satria Kendari as the response of teacher through conversation during the initial observation that needs the guidance of teachers and students to follow a series of scientific experience as well as the basis of consideration for the characteristics of the subject matter "Numbers" is not too difficult to construct contextual issues in the daily lives of students.

The result of observation of students' spiritual attitude in grade VII.B of Junior High School of Satria Kendari on scientific plus learning approach for 
mathematics courses with subject matter "Numbers" from cycle I, II, III, and IV were in good category. The students' spiritual attitude scores are presented in the following table..

Tabel 1. Distribution of Final Score of Students' Spiritual Attitudes Observation

\begin{tabular}{cccc}
\hline No & Final Score & Frequency & Category \\
\hline 1. & $3,66-4,00$ & 1 & Very good \\
2. & $2,66-3,65$ & 29 & Good \\
3. & $1,66-2,65$ & 3 & Enough \\
4. & $1,00-2,65$ & 0 & Less \\
\hline
\end{tabular}

Students' social attitude observation in grade VII.B of Junior High School of Satria Kendari under scientific plus learning approach with the subject matter "Numbers" were in good category. The students' social attitude scores are described as follows.

Tabel 2. Distribution of Final Score of Social Attitude

\begin{tabular}{cccc}
\hline No & Final Score & Frequency & Category \\
\hline 1. & $3,66-4,00$ & 6 & Very good \\
2. & $2,66-3,65$ & 27 & Good \\
3. & $1,66-2,65$ & 0 & Enough \\
4. & $1,00-2,65$ & 0 & Less \\
\hline
\end{tabular}

The results of observation on students' skills of grade VII.B of Junior High School of Satria Kendari use pattern in all Mathematics learning improvement cycles of material Numbers through scientific plus learning approach obtaining predicate B + with frequency was 12 . The students' skills scores are presented in the following table.

Tabel 3. Distribution of Final Score of Students' Skills

\begin{tabular}{cccc}
\hline No & Final Score & Predicate & Frequency \\
\hline 1. & $3,67-4,00$ & A & 9 \\
2. & $3,34-3,66$ & A- & 5 \\
3. & $3,01-3,33$ & B+ & 12 \\
4. & $2,67-3,00$ & B & 6 \\
5. & $2,34-2,66$ & B- & 1 \\
6. & $2,01-2,33$ & C+ & 0 \\
7. & $1,67-2,00$ & C & 0 \\
8. & $1,34-1,66$ & C- & 0 \\
9. & $1,01-1,33$ & D+ & 0 \\
10. & $0,00-1,00$ & D & 0 \\
\hline
\end{tabular}

Description of predicate of students' knowledge in grade VII.B of Junior High School of Satria Kendari on mathematics learning material Numbers based on the average score of learning achievement of all cycles through a scientific plus approach obtained the average score was 79.96 with percentage of completeness was 81.81 and predicate A. In other words, it had met the indicators in this research. The mathematics learning achievement scores of each cycle are presented in the following table. 
Tabel4 Distribution of Final Score of Students' Mathematics Learning Achievement

\begin{tabular}{ccccc}
\hline No & Cycle & Predicate & Average & Percentage \\
\hline 1. & I & B+ & 78,15 & $51,51 \%$ \\
2. & II & B+ & 78,33 & $54,54 \%$ \\
3. & III & A & 79,51 & $57,57 \%$ \\
4. & IV & A- & 79,96 & $81,81 \%$ \\
\hline
\end{tabular}

The result of observation on the learning management conducted by teachers and the implementation of scientific plus approach through the checklist observation sheet indicated that the lesson plans had been carried out for: cycle I was $46 \%$, cycle II was $80 \%$, cycle III was $85 \%$ and cycle IV was $86 \%$.

\section{Conclusion}

Based on the results, it can be concluded that in this research, the students' mathematics learning achievement of grade VII.B of Junior High School of Satria Kendari on the material Numbers can be increased through scientific plus learning.

\section{Disclosure statement}

No potential conflict of interest was reported by the authors.

\section{Notes on contributors}

La Ode Ahmad Jazuli, Halu Oleo University, Indonesia

Mustamin Anggo, Halu Oleo University, Indonesia

Utu Rahim, Halu Oleo University, Indonesia

Latief Sahidin, Halu Oleo University, Indonesia

Salim, Halu Oleo University, Indonesia

\section{References}

Ahiri, Jafar. (2008). Faktor- Faktor yang Mempengaruhi Hasil Belajar. Kendari: Unhalu Press.

Beckmann, A Et Al. (2009). The Science Math Project. Germany: The Science Math-Group

Budiyanto, Moch. Agus Krisno.,Waluyo, Lud., Mokhtar, Ali. (2016). Implementasi Pendekatan Saintifik dalam Pembelajarandi Pendidikan Dasar di Malang. Proceeding Biology Education Conference, 13(1),46-51.

Idris, Invany, \&Silalahi, Desri Kristina. (2016). Penerapan Pendekatan Pendidikan Matematika Realistik Indonesia(PMRI) untuk Meningkatkan Kemampuan Penyelesaian Soal Cerita padaKelas VII A SMP UTY. Jurnal EduMatSains, 1 (1), 73-82.

Jazuli, L.A. (2007). Pembelajaran Matematika Realistik untuk Subtopik Luas Permukaan Kubus, Balok, Prisma, dan Limas Di Kelas VIII SMP Negeri 5 Kendari. Surabaya: Universitas Negeri Surabaya.

Jazuli, L.A., dkk.( 2010). Workshop Penelitian Tindakan Kelas (PTK) bagi Guru-Guru Sekolah Dasar Kabupaten Wakatobi. Kendari: Universitas Halu OLeo.

Kemendikbud. (2013). Peraturan menteri pendidikan dan kebudayaan Nomor 65. Jakarta: Kementerian Pendidikan dan Kebudayaan Republik Indonesia.

Machin, A. (2014). Implementasi Pendekatan Saintifik, Penanaman Karakter Dan Konservasi Pada Pembelajaran MateriPertumbuhan. Jurnal Pendidikan IPA Indonesia, 3 (1), 28-35.

Sardiman A. M. (2007). Interaksi dan Motivasi Belajar Mengajar. Jakarta: Raja Grafindo Persada. 
Varelas, M and Ford M. (2009). The scientific method and scientific inquiry: Tensions in teachingand learning. USA: Wiley InterScience. 